\title{
Desert distributions during the glacial maximum and climatic optimum: Example of China
}

\author{
Institute of Geology, Chinese Academy of Sciences, P. O. Box 9825, Beijing 100029, China
}

The last two extreme scenarios of a glacial maximum and a Holocene climatic optimum marked extreme situations in China. The margin of deserts changed mainly in its longitudinal range due to changes in East Asia monsoonal circulations driven by the glacial boundary conditions, and it shifted from $125^{\circ} \mathrm{E}$ during the last glacial maximum to $105^{\circ} \mathrm{E}$ during the climatic optimum. The desert distribution at the LGM (Last Glacial Maximum) and the Holocene optimum in China will provide better constraints for sensitivity test experiments with general circulation models to isolate the impact of dust on regional and global climates.

\section{Introduction}

The present GCM (General Circulation Model) modeling used a lot of boundary conditions such as sea-surface temperature, glaciers, land albedo, sea-land and so on for climate modeling of the past. As a matter of fact, changes in desert distributions can lead to the variations of albedo as well as aridity through various biogeochemical feedback (Schlesinger et al., 1990). Such changes in radiation balance are likely to affect regional climate and potentially lead to further decreases in regional rainfall. Thus, the worldwide desert distributions must be considered by the GCM modeling. In addition, dust from arid regions makes a significant contribution to the burden of tropospheric aerosols. The airborne dust can lead to the climatic cooling, and it may thus offset the effects of increasing concentrations of greenhouse gases (Schlesinger et al., 1990). Moreover, recent studies indicated that dust from Asia dominates the entire Pacific north of the Intertropical Convergence Zone (Merrill et al., 1989; Duce et al., 1991), and China is considered as one of the two dominant source regions for atmospheric mineral aerosol (Rea, 1994). However, evaluation of the paleoclimatic aspects of aerosol raised from China must be based upon the desert distributions, so, in this respect, it is also necessary to determine the fossil extents of deserts in China.

By now, environmental reconstruction of many sand seas has been completed especially for the two specific time slices at $18 \mathrm{ka}$ and $6 \mathrm{ka}$ (Sarnthein, 1978; Petit-Maire, 1986, 1990, 1991, 1992; Pachur and Hoelzmann, 1991; Lancaster, 1990). Nevertheless, the fossil extents of sandy deserts during the last two extreme climatic scenarios in China have not been studied, so there exists a great gap between the past desert distribution in China and that in the other regions of the world.

This paper aims to reconstruct the fossil extents of deserts during the glacial maximum and climatic optimum in China.

\section{Physiography of desert regions in northern China}

Present deserts of northern China mainly distribute in the interiors of China between $35^{\circ}-50^{\circ} \mathrm{N}$ and $75^{\circ}-125^{\circ} \mathrm{E}$, forming an E-W trending mid-latitude desert belt. The area of desert cover in China is $1533,000 \mathrm{~km}^{2}$, nearly $15.9 \%$ of the whole country. These deserts can be divided into two parts by the north-south stretching Helan Mountain (Figure 1). Deserts in the western part including Taklimakan, Gurbantunggut (Junggar) and Qaidam are mainly distributed in three large inland basins-Tarim, Junggar and Qaidam. The surrounding mountains including Tianshan, Kunlun and Qilian with an. average elevation of more than 4000 meters, block the penetration of moist air masses from the Pacific and Indian Oceans. Another desert, named Badain Jaran, also occurs in the western desert regions of northern China. This desert is characterized by the existence of high sand hills, with an average height of $300 \mathrm{~m}$. The climate in these deserts, except the Gurbantunggut (Junggar) Desert, is controlled by the westerlies; the precipitation is less than $200 \mathrm{~mm}$ and active sand dunes are widespread. Deserts in the eastern part lie in the East Asia monsoon zone, and with a semi-arid climate, the precipitation of monsoon rainfall varies from 200 to $400 \mathrm{~mm}$. Most of the sand dunes are semi-stabilized, and the occurrence of these dunes is mainly attributed to reactivation of the last glacial sand dunes under the disturbance of poor land-use practice during the historical time.

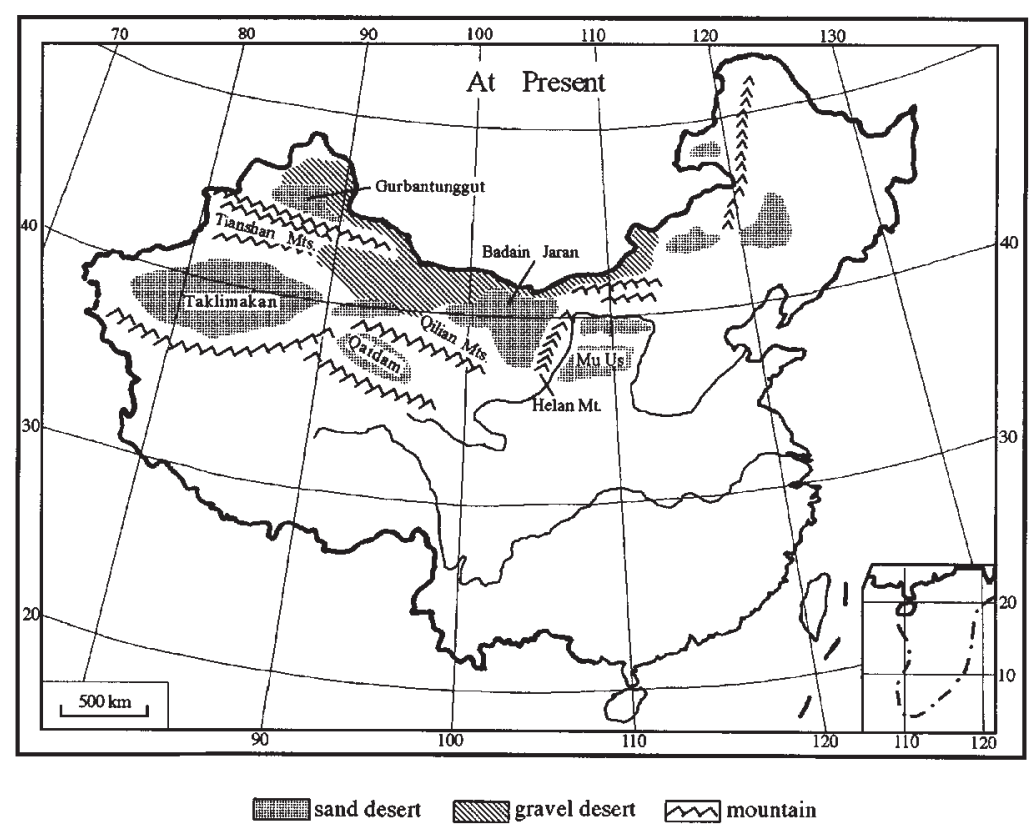

Figure 1 Present distribution of desert s in China. 


\section{The last glacial maximum}

Recent studies indicate that the variations in global ice volume may have played a key role in modulating the strength and pacing the timing of the East-Asia paleomonsoon (Ding et al., 1995). During the last glacial maximum, the enlarged high-latitude ice sheets of the Northern Hemisphere intrigued the Siberian High, cold streams were injected to the mid-latitude China, giving rise to a steeper gradient of temperature and then a more enhanced cold-dry northwest winter monsoon. Under such prevalent winds, strong eolian ablation and dune building characterized the arid and semi-arid regions of northern China.

Field investigation has shown that the Holocene sandy loam soils in northern China are usually underlain by dune sands. The thickness of these dune sands is generally between 2 and $5 \mathrm{~m}$. Thermoluminescence dating indicated that they were accumulated between 10.5 and $27 \mathrm{ka}$, broadly coincident with the last glacial maximum (Figure 2). One example of dune sands of this period from Mu Us Desert is shown in Figure 2.

These last glacial dune sands are light yellow-orange (10 YR 8/4) to dull yellow-orange (10 YR 7/4) unconsolidated sands. Typically, more than $82 \%$ of this deposit has grains $>63 \mu \mathrm{m}$, with the average grain size about $109 \mu \mathrm{m}$. Generally, within a sand layer the grains become finer from bottom to top.

For the past 10 years, 44 profiles with the last glacial sand dunes have been found in the eastern part of northern China (Figure 3a), and all these profiles occur in the monsoonal climatic zone.

A striking geomorphological feature of the present landform in China is that in the eastern part of northern China most of the semistabilized sand dunes occur in the areas with an average monsoonal rainfall between 200 and $400 \mathrm{~mm}$ and active sand dunes can only be found in some over-cultivated areas. Evidence has shown that the earliest land reclamation in the semi-arid region of northern China occurred in the Han Dynasty about 2200 years ago, but over-cultivation mainly happened during A. D. 1368-1910 of the Ming and Qing Dynasties. Obviously, the deserts now distributed in the monsoonal climatic zone of northern China are mainly attributed to the resuscitation of the 'dormant' last glacial sand dunes caused by poor landuse practices of the historical time. Therefore, to some extent, the present eolian sand sheets and sand dunes of northern China can indicate the past distribution of deserts, particularly during the last glacial maximum.

Thus, on the basis of field investigation and the combination with the available aerial photographs, we can map the deserts distribution during the last glacial maximum of China (Figure 3a). Obviously, during the last glacial maximum, the southern margin of the
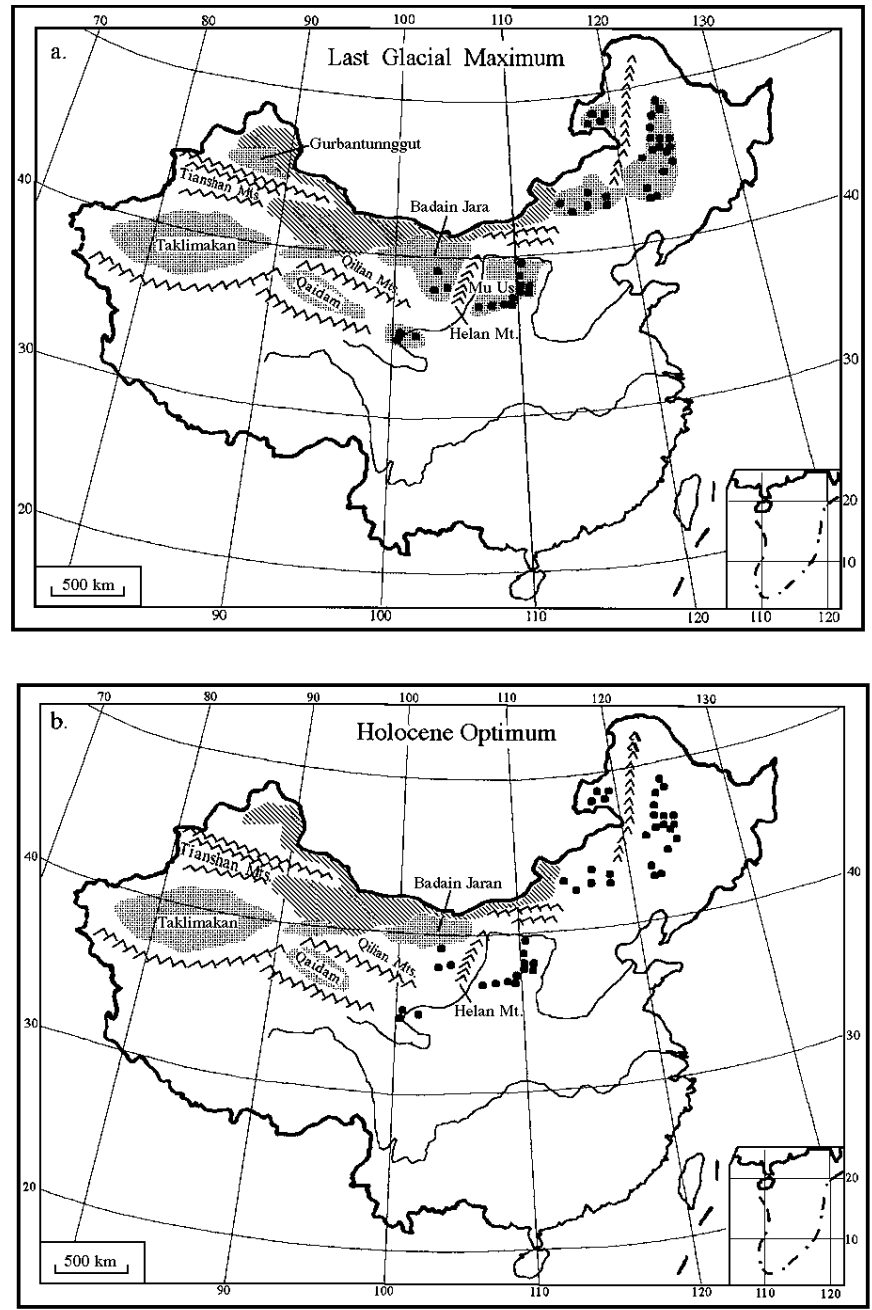

패

Figure 3 Distribution of deserts during the last glacial maximum (a) and the Holocene optimum (b). Solid dots indicate the sites where the Holocene loam soils and the underlying sand dunes of the last glacial maximum were found.
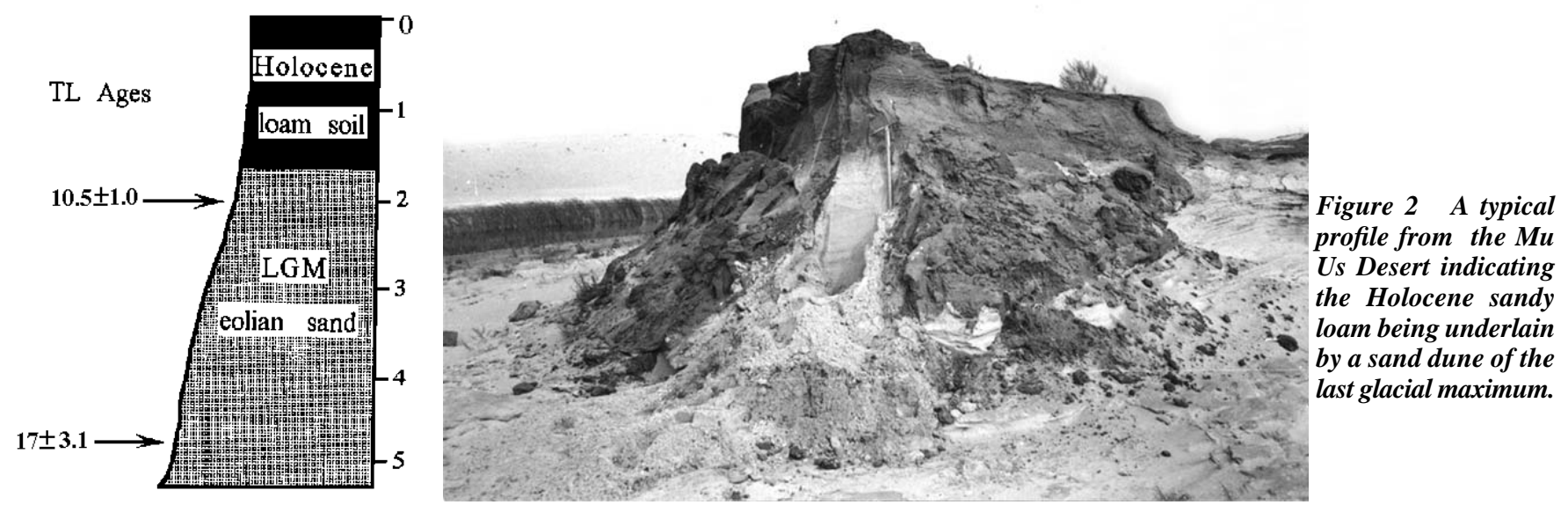
deserts extended to nearly $36{ }^{\circ} \mathrm{N}$, and its eastern boundary to $125^{\circ} \mathrm{E}$. The dune patterns at $18 \mathrm{ka}$ in China nearly resemble those of the present desert distribution.

\section{The Holocene Optimum}

During the Holocene optimum, the ice-sheet at the high latitude of the Northern Hemisphere retreated and the sea level rose about 100$120 \mathrm{~m}$ in the South China Sea, as compared with that of the last glacial maximum ( Wang, et al., 1990 ). In winter, the Siberian High weakened, and both the strength and duration of the northwest winter monsoon were greatly reduced. In summer, the strengthened high cell over the north Pacific Ocean intensified the East Asia summer monsoon, resulting in more humid air masses being transported from the north Pacific Ocean to the northwest interiors of China.

The changes in the monsoonal circulation made the pattern of the Holocene climatic optimum radically different from that of the last glacial maximum. Sandy loam soils were widely developed in the eastern part of northern China, and most topographic depressions were occupied by lakes or swamps resulting from the increased precipitation.

The Holocene sandy loam soils are characterized by an A/C profile ( see Figure 2), with a dark brown (7.5 YR 3/2) humus 'A' horizon and a weak granular structure, and the transition from these soils to the underlying dune sands of the LGM is gradual. Thin sections of these loam soils have also been examined under the microscopes and they show a weakly-developed spongy microstructure, implying that all the soils were developed under steppe environments ( Pawluk and Bal, 1985).

Nearly more than 100 radiocarbon datings have been done for these loam soils, and the results indicated that they were mainly developed between 3.0-9.0 ka BP, broadly coincident with the Holocene optimum.

Additionally, in the Loess Plateau, the uppermost paleosol $\mathrm{S}_{0}$ is also a typical loam soil and characterized by the A/AC/C profile. It has been ${ }^{14} \mathrm{C}$ dated throughout the Loess Plateau from about 2 - 9.9 ka (Liu, T.S., 1985). This loam soil can be related to the sandy loam soil in the northern desert regions. Therefore, during the Holocene optimum, humid environments such as that of soil formation was established from the Loess Plateau of Central China to the eastern desert regions of northern China.

Nevertheless, during the Holocene optimum, even the enhanced summer monsoon could not penetrate into the interior of the western desert regions. According to the recent studies (Gao et al., 1996), very thin and weakly-developed Holocene soil can be found only along the southern boundary of the Badain Jaran Desert, which means most of the sand dunes in the desert were active during the Holocene optimum. Lack of Holocene soils in the Taklimakan and Qaidam deserts indicates that active dune fields still exist in these deserts. What we now want to stress is the special circumstances of the Gurbantunggut Desert. This desert is located to the north of the E-W Tianshan Mountains, and it is the only place of the western desert regions in northern China with present precipitation of about $200 \mathrm{~mm}$. More than $95 \%$ of the sand dunes in this desert are stabilized or semi-stabilized. The present meteorological data clearly indicate that the Gurbantunggut Desert is a specific region with relatively high precipitation. If this climatic pattern existed during the Holocene optimum, there would be more precipitation in the Gurbantunggut Desert. Although less work has been done for the geological past of this desert, we can speculate that during the Holocene optimum this desert was 'dormant'.

Thus, during the Holocene optimum, active dune fields were only restricted to the Taklimakan, Qaidam and part of the Badain Jaran deserts (Figure $3 b$ ). The eastern margin of the deserts retreated from $125^{\circ} \mathrm{E}$ during the last glacial maximum to about $105^{\circ} \mathrm{E}$ in the Holocene optimum.

\section{Conclusion}

In the past $20 \mathrm{ka}$, the mid-latitude arid belt in northern China underwent wide changes mainly in its longitudinal range due to changes in East Asia monsoonal circulations driven by the glacial boundary conditions. During the last glacial maximum, the desert extended eastwards to $125^{\circ} \mathrm{E}$. During the Holocene optimum, it was replaced by steppe environments and extended westwards to $105^{\circ} \mathrm{E}$. The present dune patterns in China rather resemble those of the last glacial maximum, but are radically different from those of the Holocene optimum. We think that the ice sheet at high latitude of the Northern Hemisphere is likely to play a great role in controlling the spatial shifting of desert limits in northern China. The desert distributions at the LGM and Holocene optimum in China will provide better constraints for sensitivity test experiments with general circulation models to isolate the impact of dust on regional and global climates.

\section{Acknowledgements}

This work is jointly sponsored by the National Natural Science Foundation of China (Grant 49894170 and Grant 49602034) and the Chinese Academy of Sciences (Grant KZ951-A1-402). Thanks are due to Prof. Guo Zhengtang and Dr. Gu Zhaoyan for their helpful discussion.

\section{References}

Ding, Z. L., Liu, T. S., Rutter, N. W., Yu, Z. W., Guo, Z. T., and Zhu, R. X., 1995, Ice-volume forcing of East Asia winter monsoon variations in the past 800, 000 years: Quaternary Research, v.44, pp.149-159.

Duce, R. A. et al., 1991, The atmospheric input of trace species to the world ocean, Global Biogeochem: Cycles, v.5, pp. 193-259.

Gao, Q. Z., Dong, G. R., Zou, X. Y., and Li, B. S., 1996. The Chagelebulu section: A strata record of the advances and retreats of the monsoons in East Asia since Late Pleistocene: Journal of Desert Research, v.16, pp. $112-119$

Merrill, J. T., Belck, R., and Uematsu, M., 1989, Meteorological analysis of long-range transport of mineral aerosols over the North Pacific: J. Geophys. Res., v. 94 , pp. 8584-8598.

Lancaster, N., 1990, Palaeoclimatic evidence from sand seas: Palaeogeography, Palaeoclimatology, Palaeoecology, v.76, pp. 279-290.

Liu, T.S., 1985, Loess and the Environment, pp.31-238.

Pachur, H. J., and Hoelzmann, P., 1991, Paleoclimatic implications of late Quaternary lacustrine sediments in western Nubia, Sudan: Quaternary Research, v. 36, pp. 257-276.

Pawluk, S. and Bal, S., 1985, Micromorphology of selected mollic epipedons, in Douglas L. A. and Thompson, M. L. (editors), Soil Micromorphology and Soil Classification, pp. 63-84.

Petit-Maire, N., 1986, Paleoclimates in the Sahara of Mali: a multidisciplinary study: Episodes, v.9, pp.7-16.

Petit-Maire, N., 1990, Will greenhouse green the Sahara? Episodes, v.13, pp. 103-107.

Petit-Maire, N. and Page, N., 1992, Remote sensing and past climatic changes in tropical deserts: example of the Sahara: Episodes, v.15, pp.113-117.

Rea, D. K., 1994, The paleoclimatic record provided by eolian deposition in the deep sea: the geological history of wind: Rev. Geophys., v. 32, pp.159-195.

Sarnthein, M., 1978, Sand deserts during the glacial maximum and climatic optimum: Nature, 272, pp. 43-46.

Schlesinger, W. H., Reynolds, J. F., Cunningham, G. L., Huenneke, L. F., Jarrell, W. M., Virginla, R. A., and Whitford, W. G., 1990, Biological feedbacks in global desertification: Science, v.247, pp.1043-1048.

Wang, P. X., 1990, The China Seas in the last glacial stage: status and problems: Quaternary Sciences, v. 2, pp. 111-124. 
Sun Jimin was born in Shandong, China, on November 20, 1965. He received his PhD in Quaternary from the Institute of Geology, Chinese Academy of Sciences in 1994. He was a postdoctoral researcher in palaeoclimatology from 1994 to 1996. At present, he is an Associate Professor of the Institute of Geology, Chinese Academy of Sciences. His research interests are in the aspects of palaeoenvironmental reconstruction in arid and semi-arid regions.

Ding Zhongli received his $P h D$ in Quaternary from the Institute of Geology, Chinese Academy of Sciences in 1988. At present, He is a Professor of the Institute of Geology, CAS. He is active in the study of past global changes. His main research interests focus on palaeoclimatology and palaeoenvironment.

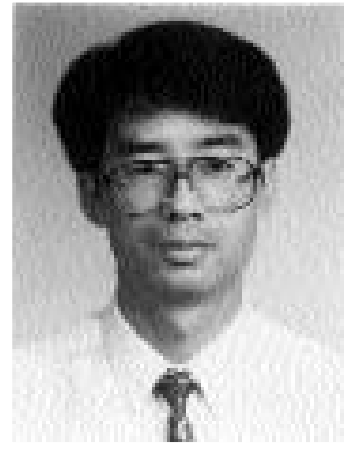

Liu Tungsheng is an Academician of the Chinese Academy of Sciences. He was the President of INQUA from 1991 to 1995. He is currently Chairman of CHIQUA (China Quaternary Research Association). $\mathrm{He}$ is a Quaternary geologist and environmental geologist. He is now organizing an international group to work on the PEP II project, which is the Australia-Asia transect and will promote the extraction of new, highresolution records with particular attention to the palaeomonsoon as a tele-connection process in tropical and subtropical regions. It will also be central to developing a clearer understanding of the influence of the Tibetan Plateau on global change.

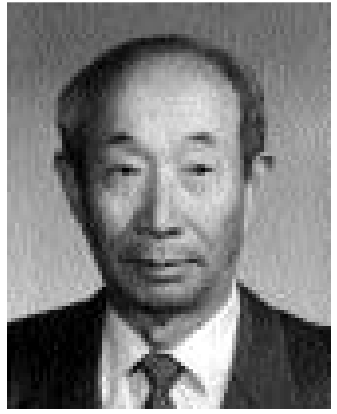

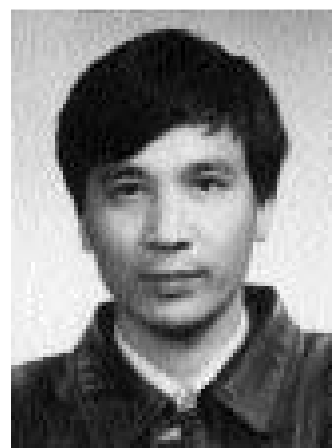

\title{
JOIN THE ARAB GEOLOGISTS'S ASSOCIATION NOW
}

The Arab Geologists Association (AGA) is a pan-Arab professional scientific and consulting geological organisation. It embraces within its ranks geologists unions and geological societies in 11 Arab countries representing about 10,000 professional Arab geologists. Recent amendments of the statutes of the association introduced a new membership category, i.e., associate membership. This membership is open to Arab and foreign institutions operating inside and outside the Arab world against an annual subscription fee of US\$ 500 . The associate member is entitled to the followings:

1. Recieving free of charge AGA's publications, including the Association's News Magazine, Geoscience \& Arab Development.

2. Receiving announcements of AGA meetings and other activities.

3. A membership discount when participating in AGA conferences, symposia, and exhibitions.

4. A membership discount when advertising in the News Magazine, Geoscience \& Development.

For further information, please write to:

\author{
Secretary General \\ Arab Geologists Assciation \\ P.O. Box 1247, Postal Code 12112 \\ Baghdad, Iraq \\ Fax: 964-1-2869432
}

